\title{
Reproductive failure, possible maternal infanticide, and cannibalism in wild moustached tamarins, Saguinus mystax
}

\author{
Laurence Culot • Yvan Lledo-Ferrer • \\ Oda Hoelscher · Fernando J. J. Muñoz Lazo • \\ Marie-Claude Huynen · Eckhard W. Heymann
}

Received: 6 September 2010/Accepted: 24 January 2011/Published online: 17 February 2011

(C) Japan Monkey Centre and Springer 2011

\begin{abstract}
Maternal infanticide in wild non-human primates has only been reported twice. In this paper, we report a possible new case of infanticide and cannibalism within a series of four successive reproductive failures in wild moustached tamarins, Saguinus mystax. Necropsy and genetic analyses of the corpses enabled us to rule out any pathology, and to determine paternity. The mother was seen biting and then eating the head of its own infant during a period when another female was pregnant and gave birth just 1 month later. Before that, the perpetrator had given birth to twins three times successfully when four to five adult and subadult males were present in the group. Although we do not know for certain that the infant was alive when the mother started biting it, our field observations preceding the event suggest it probably was. The possible infanticide case and the two cases of births and
\end{abstract}

Electronic supplementary material The online version of this article (doi:10.1007/s10329-011-0238-6) contains supplementary material, which is available to authorized users.

L. Culot $(\bowtie) \cdot$ M.-C. Huynen

Primatology Research Group, Behavioural Biology Unit,

University of Liège, Quai van Beneden, Bât. I1,

4020 Liège, Belgium

e-mail: Laurence.Culot@ulg.ac.be

L. Culot · Y. Lledo-Ferrer · O. Hoelscher · E. W. Heymann

Abteilung Verhaltensökologie and Soziobiologie,

Deutsches Primatenzentrum (DPZ), Göttingen, Germany

Y. Lledo-Ferrer

Area de Psicobiología, Universidad Autónoma de Madrid,

Madrid, Spain

F. J. J. Muñoz Lazo

Departamento de Ecología y Fauna, Universidad Nacional de la

Amazonia Peruana, Iquitos, Peru early death of the infants occurred while only two to three adult males were present in the group. This could be the second case of maternal infanticide reported in the genus Saguinus and the similar circumstances suggest a common pattern. We discuss these events in the light of the different functional explanations of infanticide and conclude that parental manipulation was the most likely: the mother could have terminated the investment in offspring that had low chances of survival in a group with low availability of helpers.

Keywords Callitrichidae - Cannibalism - Infanticide . Multiple breeding $\cdot$ Parental manipulation

\section{Introduction}

Infanticide has been defined as any behaviour performed by an individual or group of individuals that leads to the immediate or imminent death of an immature conspecific (Digby 2000). This behaviour has been described, in the wild and under laboratory conditions, in a wide variety of mammalian taxa (reviewed in Ebensperger 1998). Five common hypotheses are provided to try to explain this behaviour: exploitation, resource competition, parental manipulation, sexual selection, and social pathology (Hrdy 1979). The most accepted explanation, the sexual selection hypothesis, states that it would be advantageous for a male to kill unrelated infants in order to gain reproductive access to females (Digby 2000) as the females are likely to resume cycling soon after the killing. For most callitrichine species, however, the killing of dependent young would have a minimum effect on the mother's resumption of fertility, because lactation has little or no inhibitory effect on ovulation (Abbott et al. 1993; French 1997; Digby et al. 2007) 
and post-partum ovulation occurs as soon as 12-32 days after parturition (Lunn and McNeilly 1982). Correspondingly, infanticide by males has never been reported in wild callitrichines (Digby and Saltzman 2009) wherreas infanticide by females has been observed on ten occasions (Table 1).

Seven of these ten infanticides were perpetrated by females that were not the mothers of the killed infants. Of these seven, five were pregnant females $(C$. jacchus) and two were dominant, non-pregnant females ( $C$. flaviceps and C. jacchus). One additional infanticide was perpetrated by an unknown individual (C. flaviceps) and two by the mothers (Saguinus). Infanticide perpetrated by females on other females' offspring have also been reported in other cooperatively breeding mammals including meerkats (Suricata suricatta), wild dogs (Lycaon pictus), dingos (Canis familiaris dingo), and brown hyaenas (Hyaena brunnea) (Clutton-Brock et al. 1998; Digby 2000).

Callitrichines undergo unusually high reproductive costs: they have a long gestation period in relation to their small body size and usually give birth to heavy dizygotic twins that represent $16-20 \%$ of the mother's body mass (Tardif et al. 1993; Ziegler et al. 1987). Transport of the infants is also a costly activity which causes loss of body mass of the carriers, even under captive conditions (Sanchez et al. 1999; Achenbach and Snowdon 2002; Sanchez et al. 2005). These high cost are borne by a cooperative breeding system in which all group members, related or not to the infants, participate in carrying those of the only reproductive female (Emlen 1991; Solomon and French 1997). Indeed, it has been shown that one single pair of saddleback tamarins, Saguinus fuscicollis, could hardly raise infants (Goldizen 1987). However, a growing body of evidences indicates that the once thought general reproductive inhibition of subordinate females in the group by a single breeding female is not universal. The occurrence of multiple breeding is common in Callimico (Goeldi's monkey, Encarnación and Heymann 1998; Porter 2001), but in Callithrix (marmosets), Leontopithecus (lion tamarins), and Saguinus (tamarins) it results in reduced offspring survival for one of the breeding females (Dietz and Baker 1993; Roda and Mendes Pontes 1998; Smith et al. 2001).

Direct maternal infanticide is common in farm animals including pigs, rabbits (Sambraus 1985), and sheep (Fraser and Broom 1990), and indirect maternal infanticide (rejection of offspring) has been observed in wild carnivores such as grizzly bears (Tait 1980). In non-human primates, maternal infanticide in the wild is very rare (Hrdy 1999) and, before this study, has been reported once in S. fuscicollis, at the EBQB study site, and once in Callicebus nigrifrons (Tirado-Herrera et al. 2000; Cäsar et al. 2008). In this paper, we report a series of four infant losses in a group of moustached tamarins, Saguinus mystax, with multiple breeding females. These losses include one possible case of maternal infanticide, the third case described in wild non-human primates which is also the first case in S. mystax. We analysed these events in their demographic context (number of helpers and breeding females) and discuss the observations in the light of different functional interpretations of multiple breeding and infanticide in primates.

\section{Methods}

This study was conducted at the Estación Biológica Quebrada Blanco (EBQB), located $80 \mathrm{~km}$ south-east of Iquitos,

Table 1 Infanticide and cannibalism reports in wild callitrichines (adapted from Digby and Saltzman 2009) with the likely explanation according to the respective authors

\begin{tabular}{|c|c|c|c|c|}
\hline Species & Perpetrator & Cannibalism & Likely explanation & References \\
\hline Callithrix jacchus & Pregnant female & No & Resource competition (food) & (Roda and Mendes Pontes 1998) \\
\hline Callithrix jacchus & Pregnant female & No & Resource competition (helpers) & (Digby 1995; Nievergelt et al. 2000) \\
\hline Callithrix jacchus & Pregnant female & No & $\begin{array}{l}\text { Not mentioned } \\
\text { (sexual selection likely) }\end{array}$ & (Arruda et al. 2005) \\
\hline Callithrix jacchus & Pregnant female & Yes & Sexual selection & (Lazaro-Perea et al. 2000) \\
\hline Callithrix jacchus & $\begin{array}{l}\text { Dominant female } \\
\text { (neighbouring group) }\end{array}$ & Yes & $\begin{array}{l}\text { Resource competition } \\
\text { and exploitation }\end{array}$ & (Melo et al. 2003) \\
\hline Callithrix jacchus & Pregnant female & Yes & $\begin{array}{l}\text { Sexual selection (reproductive } \\
\text { dominance) }\end{array}$ & (Bezerra et al. 2007) \\
\hline Callithrix flaviceps & $\begin{array}{l}\text { Unknown-Dominant female } \\
\text { (double infanticide) }\end{array}$ & No-Yes & Resource competition (helpers) & (Hilário and Ferrari 2010) \\
\hline $\begin{array}{l}\text { Saguinus } \\
\text { fuscicollis }\end{array}$ & Mother & Yes & Parental manipulation & (Tirado-Herrera et al. 2000) \\
\hline Saguinus mystax & Mother & Yes & Parental manipulation & This study \\
\hline
\end{tabular}


Peru $\left(4^{\circ} 21^{\prime} \mathrm{S}, 73^{\circ} 09^{\prime} \mathrm{W}\right)$, in primeval Amazonian lowland forest (see Heymann 1995 for details of the study site). A well-habituated group of $S$. mystax, forming a mixed-species troop with $S$. fuscicollis, was followed from exiting a sleeping site (usually between 0515 and $0600 \mathrm{~h}$ ) to retiring to a sleeping site (usually between 1500 and $1630 \mathrm{~h}$ ). Both species were fully habituated to the presence of observers. All animals were individually recognizable through natural marks (e.g., genital shape and pigmentation, shape of the tail, etc.; Löttker et al. 2004). Group composition and special events were recorded by the authors from May 2004 to June 2008 in the context of other studies.

We followed the $S$. mystax 2 weeks per month. We collected routine data with instantaneous scan-sampling at $10 \mathrm{~min}$ intervals and included individual activity and location of group within the home range. Particular events were recorded ad libitum, describing the event and the circumstances in as much detail as possible. Throughout the manuscript, we refer to adult females as F- $x$, adult males as M- $x$, subadult females as SF- $x$, subadult males as SM- $x$, juvenile males as JM- $x$, and juvenile females as JF- $x$.

After each infant death, the corpse was collected and immediately stored in $96 \%$ ethanol at ambient temperature. Additionally, faecal samples of all group members were collected within the day after the infanticide event and stored under the same conditions in order to determine the parents of each dead infant by parentage analysis. Macroscopic, histological, microbiological, and parasitological examination of the dead infants was performed in the Department of Infection Pathology of the German Primate Centre (Göttingen, Germany). Genetic analysis was performed following Huck et al. (2005) (see supplementary material for further details). Unless otherwise specified, the identities of the father and the mother of the dead infants were confirmed by the genetic analysis.

In order to determine whether infant survival to 3 months (which represents the main nursing period; Tardif 1994) was linked to the presence of multiple breeding females and/or the number of male helpers, we analysed data from 1999 to 2008 of the EBQB $S$. mystax population consisting of three different groups (Smith et al. 2001; Löttker et al. 2004; M. Stojan-Dolar unpublished data; and this study). We performed a Pearson chi-squared test to determine whether infant survival significantly differed when one or two breeding females were present. We used logistic regression to determine whether the number of male helpers affected infant survival (response variable: lives or dies within 3 months after birth). We compared the median number of male helpers when infants (considered independently, not in pairs) survived or did not, with a Mann-Whitney $U$ test. All statistical analysis was twotailed and performed by use of Statistica 9 software, with the $\alpha$ level set at 0.05 .

\section{Results}

Group composition and births

From May 2004 to March 2007, the S. mystax group contained 6-10 individuals including one single adult female F-1. During this period, we registered three births of twins and the disappearance of only one infant at 6 months of age. From April 2007 to June 2008, the S. mystax group contained 4-9 individuals including two adult females (F-1 and F-2, F-2 being the daughter of F-1). F-1 gave birth to two set of twins and F-2 to one set of twins, all of which died or disappeared before 15 days of life (Table 2). The sequence of births in the demographic context (number of breeding females and male helpers) is given in Fig. 1.

1st death: mother $=\mathrm{F}-1$, father not sampled

The group contained two adult females (F-1, F-2), two juvenile females (JF-1, JF-2), and three adult males (M-1, M-2, M-3). On August 15th 2007, a male infant, about 2 weeks old, fell from about $25 \mathrm{~m}$ height $(0818 \mathrm{~h})$. One unidentified adult male and an unidentified adult female of the group descended to the ground and, after several attempts, the male picked it up and the group continued its progression. About $40 \mathrm{~min}$ later, the infant fell again from $25 \mathrm{~m}$, was picked up, fell again immediately from $5 \mathrm{~m}$ height, and was picked up once more by the same male as before. The same scene occurred 20 min later, and the infant was picked up after 5 unsuccessful attempts. Half an hour later $(1003 \mathrm{~h})$, the infant fell for the last time from $12 \mathrm{~m}$. Three males tried to pick it up, unsuccessfully, because the infant seemed unable to grab on to the adults. At $1015 \mathrm{~h}$, the group left and just one adult male still tried to pick the infant up, until $1043 \mathrm{~h}$ when he left and joined the group, leaving the infant on the ground. The corpse was collected at $1215 \mathrm{~h}$. Its twin was last seen 2 days later on 17th August, and disappeared between 18th August and mid-September 2007 while no observations were being carried out on the group.

2nd death (possible maternal infanticide):

mother $=\mathrm{F}-1$, father $=\mathrm{M}-2$

The group contained two adult females (F-1, F-2), two subadult females (SF-1, SF-2, previously JF-1 and JF-2), and two adult males (M-2, M-3). Twins were born in the night from 6th to 7 th February 2008. The next morning we noticed that the two infants were carried separately by F-1 and M-2 (normally infants are carried together during the first weeks of life). While we were following the associated saddleback tamarins in a patch of secondary forest, we observed F-1, accompanied by SF-1 and SF-2, carrying one 
Table 2 Group composition of S. mystax and special events from May 2004 to June 2008

\begin{tabular}{|c|c|c|c|c|c|c|c|c|c|c|}
\hline \multirow[t]{2}{*}{ Period } & \multicolumn{9}{|c|}{ Group composition } & \multirow[t]{2}{*}{ Special Events } \\
\hline & $\mathrm{A}_{+}$品 & $\mathrm{S}$ 早 & $\mathbf{J}_{\text {平 }}$ & $\mathrm{A} \hat{\jmath}$ & $\mathrm{S} \widehat{\jmath}$ & $\mathbf{J} \hat{\delta}$ & $\mathrm{J} ?$ & I & tot & \\
\hline $05 / 21 / 2004-10 / 23 / 2004$ & 1 & & 1 & 2 & 1 & 1 & & 2 & 8 & \\
\hline $10 / 24 / 2004-06 / 08 / 2005$ & 1 & & & 2 & 1 & & 2 & & 6 & Departure of 1 subadult male and 1 juvenile female \\
\hline 06/09/2005-06/19/2005 & 1 & & & 2 & 1 & & 2 & & 6 & \\
\hline 06/20/2005-10/02/2005 & 1 & & & 3 & 2 & & & 2 & 8 & Birth of twins (1-20/06/2005) \\
\hline 03/10/2005-08/01/2006 & 1 & & 1 & 3 & 2 & 1 & & & 8 & \\
\hline 01/09/2006-06/11/2006 & 1 & & 1 & 5 & & 1 & & 2 & 10 & Birth of twins $(22 / 12 / 2005-09 / 01 / 2006)$ \\
\hline $06 / 12 / 2006-06 / 19 / 2006$ & 1 & & 1 & 5 & & 1 & 1 & & 9 & Disappearance of 1 newborn \\
\hline 06/20/2006-07/11/2006 & 1 & 1 & & 4 & 1 & 1 & & & 8 & Departure of 1 adult male \\
\hline 07/12/2006-11/22/2006 & 1 & 1 & & 3 & 1 & 1 & & & 7 & Departure of 1 adult male \\
\hline $11 / 23 / 2006-03 / 11 / 2007$ & 1 & 1 & & 3 & 1 & 1 & & 2 & 9 & Birth of twins \\
\hline 03/12/2007-07/08/2007 & 2 & & & 4 & 1 & & & 2 & 9 & \\
\hline 07/09/2007-08/05/2007 & 2 & & 2 & 3 & & & & & 7 & Departure of 1 adult male and 1 subadult male \\
\hline 08/06/2007-08/14/2007 & 2 & & 2 & 3 & & & & 2 & 9 & Birth of twins $(27 / 07-6 / 08 / 2007)$ \\
\hline 08/15/2007-08/16/2007 & 2 & & 2 & 3 & & & & 1 & 8 & Fall and death of 1 newborn \\
\hline 08/17/2007-12/11/2007 & 2 & & 2 & 3 & & & & & 7 & Disappearance of 1 newborn (mid-September) \\
\hline $12 / 12 / 2007-02 / 06 / 2008$ & 2 & 2 & & 2 & & & & & 6 & Departure of 1 adult male \\
\hline 02/07/2008 & 2 & 2 & & 2 & & & & 2 & 8 & Birth of twins \\
\hline 02/08/2008-03/05/2008 & 2 & 2 & & 2 & & & & & 6 & $\begin{array}{l}\text { Possible maternal infanticide, } \\
\text { disappearance of } 1 \text { newborn }\end{array}$ \\
\hline 03/06/2008-03/07/2008 & 2 & 1 & & 2 & & & & & 5 & Departure of 1 subadult female \\
\hline 03/08/2008 & 2 & 1 & & 2 & & & & 2 & 7 & Birth of twins \\
\hline 03/09/2008-04/07/2008 & 2 & 1 & & 2 & & & & & 5 & Fall and death of 1 newborn, disappearance of the other \\
\hline Since the $04 / 08 / 2008$ until June 2008 & 2 & & & 2 & & & & & 4 & Departure of 1 subadult female \\
\hline
\end{tabular}

Date of the special event corresponds to the first date given in the interval when no other indications are given. Dates are given as month/day/year $A$ adult (19 months and more), $S$ subadult (13-18 months), $J$ juvenile (4-12 months), $J$ ? juvenile of which sex is unknown (4-12 months), $I$ infant ( $0-3$ months), tot total number of individuals

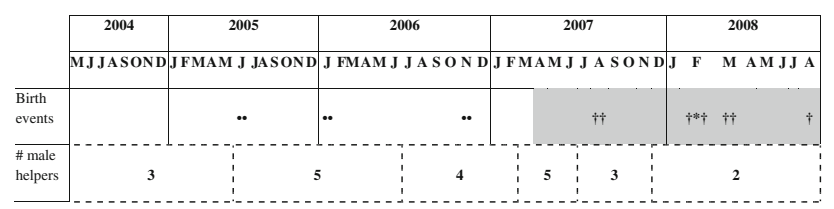

Fig. 1 Sequence of S. mystax births in the study group and the respective number of breeding females and male helpers. Grey colour represents the period during which the group contained two breeding females; filled circles represent birth of infant that survived at least 3 months; daggers represent birth of infant that died before 3 months of age; asterisk represents possible maternal infanticide

infant and feeding on a fruiting tree at $0914 \mathrm{~h}$. At $0926 \mathrm{~h}$, we heard some short-lasting chirp vocalizations from the moustached tamarins in the secondary forest. The cause could not be determined as the vocalizing individuals were not visible at that time but the sound was characteristic of the vocalization produced by an adult and an infant when the infant is not well accommodated on the back of the adult for transport (unpublished observations). At that time,
F-1 was still visible with one of the infants. At $1025 \mathrm{~h}$, while we were coming back to the primary forest with the saddleback tamarins, we observed F-1 biting and eating the head of its son. We do not know for certain that the infant was alive when the mother started biting it. However, before that, we did not hear any other vocalization from the infant or the other group members which are typical when infants fall to the ground or after predator attacks (LledoFerrer et al. 2009). We thus assume that possible infanticide can be attributed to the mother. The two subadult females SF-1 and SF-2 were vocalizing with the typical begging calls. Once F-1 had eaten the whole head, it left the corpse on a branch; F-2 took it and ate the neck and part of the shoulder. At $1036 \mathrm{~h}, \mathrm{~F}-2$ dropped the corpse to the ground, descended to search for it accompanied by SF-1 and SF-2 but left very quickly, leaving the corpse on the ground and started resting approximately $25 \mathrm{~m}$ away with the rest of the group. The corpse was then collected. The second infant was not seen any more after this event. It may have been eaten or fallen when we heard the 
vocalizations at $0926 \mathrm{~h}$. The same day, we observed that F-1 did not have swollen nipples, as should normally occur after parturition.

3rd death: mother $=\mathrm{F}-2$, father $=\mathrm{M}-2$

The group contained two adult females (F-1, F-2), one subadult female (SF-1, previously JF-1), and two adult males (M-2, M-3). One month after the 2nd death, we observed the presence of two newborns in the group (8th March 2008). Two days before (6/03/08), SF-2 had disappeared, probably migrating. At approximately $0700 \mathrm{~h}$, as we were following the saddleback tamarins, we heard some loud alarm calls from the moustached tamarins. At $0806 \mathrm{~h}$, we found a male infant on the ground, where the vocalizations had been heard, and only F-2 was close to it, vocalizing although not trying to pick it up. The rest of the group had already left, and the female joined them at $0927 \mathrm{~h}$, after one hour and a half. At $0931 \mathrm{~h}$, the saddleback and some moustached tamarins came closer to the place where the infant was lying but did not give it much attention. The corpse was collected at $0940 \mathrm{~h}$. At $0945 \mathrm{~h}$, we could observe the five moustached tamarins together and none of them was carrying an infant. The other infant was thus last seen at $0910 \mathrm{~h}$, and its corpse could not be found.

4th death: mother $=\mathrm{F}-1$ or F-2, father $=$ unknown (no genetic analyses conducted)

When regular observations were no longer being carried out by the authors, a newborn infant was observed in the group 5 months after the third death (K. Lütmann, personal communication). Both F-1 (more likely) and F-2 could have been the mother, because the mean gestation time in S. mystax is approximately 140-145 days (Harvey et al. 1987) and at least 5 months had elapsed since their last pregnancies. However, F-1 is more likely supposed to be the mother as 6 months had elapsed since its last pregnancy as opposed to exactly 5 months for F-2. Here again, the infant died after successive falls before reaching 15 days of life (K. Lütmann, personal communication), which makes a total of four successive reproductive failures within the same group.

\section{Necropsies}

Necropsy did not reveal any pathological findings in the three infants.

\section{Demographic analysis}

Breeding by multiple $S$. mystax females at EBQB is a rare event. It occurred in our study group only in 2001 (Smith

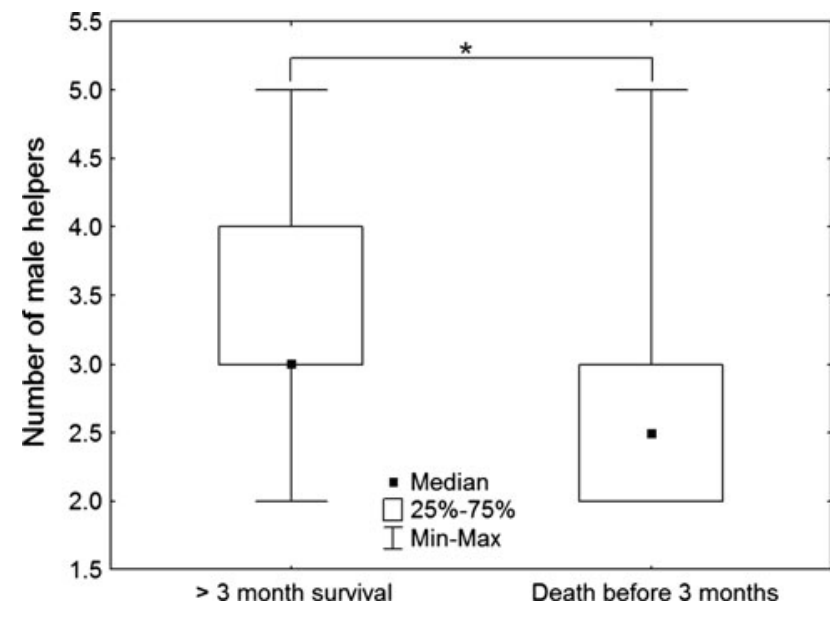

Fig. 2 Median number of male helpers per group in S. mystax population of the EBQB (three study groups) when infants survived at least 3 months $(n=26)$ or died before reaching 3 months of age $(n=14)$. Statistical differences are indicated by an asterisk $(P<0.05)$

et al. 2001) and in 2007-2008 (this study) and significantly affected infant survival to 3 months $\left(n=40, \chi^{2}=11.87\right.$, $P=0.0006)$. When two breeding females were in the group, $80 \%(n=10)$ of the infants less than 3 months old $\operatorname{died}^{1}$ whereas only $20 \%(n=30)$ died when there was a single breeding female. The number of helpers significantly affected infant survival to 3 months $\left(n=40, \chi^{2}=4.257\right.$, $P=0.039$ ). Indeed, $75 \%$ of the infants survived when at least three male helpers were present in the group whereas only $41.7 \%$ did when the group contained one or two male helpers. Surviving infants were born in a group with a median of three male helpers whereas infants that died before reaching 3 months old were born in a group with a median of 2.5 male helpers (Fig. 2). This difference was significant $(n=40, \quad U=113.0$, adjusted $Z=2.113$, $P=0.035)$.

\section{Discussion}

This is the first possible case of maternal infanticide reported for Saguinus mystax, and the second for a tamarin species. Although such observations could be considered as only anecdotal, their repetition enables us to point out some common patterns and helps determine their functional significance. Both cases of maternal infanticide in Saguinus occurred in groups with multiple breeding females (this study and Tirado-Herrera et al. 2000). The occurrence of multiple breeding in callitrichines can be increased by

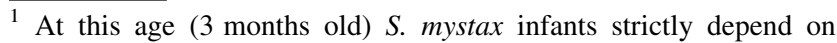
parents and helpers for food transfer and transport. Thus, emigration can be excluded and therefore only death remains an explanation when an infant disappears.
} 
several factors, for example high population density, limited opportunities for dispersal, or the presence of a male unrelated to the daughter of the dominant female (Dietz and Baker 1993; Smith et al. 2001; Vleeschouwer et al. 2001; Saltzman et al. 2004). It is interesting to note that, in our study group, F-1 was the mother of F-2, which could have led to higher tolerance from the mother towards its daughter for access to males, as observed in golden-headed lion tamarins (Vleeschouwer et al. 2001).

Our long-term records of group composition showed that the possible infanticide in S. mystax happened within a series of reproductive failures, indicating a potential problem with infant care in the group. Indeed, we have shown that infant survival is directly linked to the number of male helpers. There were four or five adult and subadult males in our study group when the infants survived but only three, and then two, when the infants died (Table 2). The possible case of maternal infanticide occurred during this second period, and was perpetrated by F-1 while F-2 was pregnant.

The number of helpers is thus crucial in determining the probability of survival of young callitrichines (Garber 1997; Heymann 2000). This may be especially true when more than one pair of twins is present in the group and several females are competing for helpers. This assumption is consistent with our results showing lower infant survival when two breeding females are present in the group. Goldizen et al. (1996) showed that births must be spaced by 3 months or more to be successful in order to allow efficient helping behaviour. In both Saguinus infanticides, the interval between the birth events of the two females was smaller than 3 months (S. fuscicollis: 2.5 months, TiradoHerrera et al. 2000, S. mystax: 1 month, this study), which would have led to a possible lack of helpers for raising two sets of twins. Competition for resources such as food but also burrows and access to helpers is often evoked as the explanation of infanticides by females in cooperative breeding species such as marmosets, meerkats, and social carnivores (Digby 2000 and references therein). However, in these cases, it is usually a dominant female (pregnant or that has just given birth) that kills the offspring of another female or prevents group members from sharing food with subordinates (Digby 2000, and references therein).

Hrdy (1979) provided several hypotheses to explain different infanticide scenarios. Our case, where the mother supposedly killed her own infant, is qualitatively different from those where a female kills another female's offspring, so the resource competition and sexual selection hypotheses must be rejected.

Although cannibalism was observed in both Saguinus species, we reject the hypothesis that the mother would have killed its offspring in order to exploit the meat. Indeed, in both cases, only the head (brain) and in the case of $S$. mystax, a small part of the neck and shoulder were consumed, leaving the rest of the corpse totally intact, which rarely happens when tamarins consume vertebrate prey such as frogs or lizards (personal observation). The "social pathology hypothesis" is also very unlikely as it predicts that infanticide should be limited to areas disturbed by humans (Curtin and Dolhinow 1978). Our study group had been fully habituated to human observers for many years and many other successful births have been observed in S. mystax and S. fuscicollis at EBQB.

Based on these considerations, we consider the "parental manipulation hypothesis" as the best explanation of maternal infanticide in Saguinus, as proposed by TiradoHerrera et al. (2000). Indeed, the circumstances of both infanticides were very similar, except that the $S$. mystax newborn apparently did not fall. However, even if the newborn was physically healthy, the mother could still have killed it because of its low probability of survival in the group, as previous and subsequent infants died, probably because of a low availability of helpers. Hrdy (1979) explained that the victim of an infanticide for parental manipulation is not necessarily defective but can simply be born at a bad time, consequently demanding a supplementary cost to the parents in terms of lifetime allocation of effort in the rearing of offspring. This observation has also been made concerning maternal infanticides in humans. Indeed, this type of infanticide is more common in humans than in non-human primates (Voland and Stephan 2000). It has been hypothesized that maternal infanticide is expected to happen only if biological reproduction occurs in a cooperative relationship. Termination of investment in infants in humans might happen when the child has a reduced reproductive value because of undesirable sex, the presence of too many siblings, young age of the mother, bad health, or simply because he is born at the wrong time (Voland and Stephan 2000). It can also happen in reaction to a lack of paternal contribution to child care. If the offspring has a low reproductive value, and if the mother already has dependent children, or is likely to have such children in the future, or if the killing of her own child increases her mating success, then maternal infanticide can be regarded as adaptative (Voland and Stephan 2000). These considerations fit with our observation of the possible $S$. mystax infanticide. The low availability of helpers combined with the pregnancy of a second female might have been created stressful conditions for the mother possibly affecting the health of the infant (Schneider et al. 1999) in a way that could not be detected by necropsies. Indeed, infants born from a stressed mother are more likely to have neuromotor and attention disorders (Schneider et al. 1999), which could have been the signal perceived by the mother for terminating the investment by killing its infant. Because F-1 and F-2 were related, F-1 would still 
gain inclusive fitness by resuming her investment and favouring the survival of F-2 offspring. Moreover, even if we consider that the exploitation hypothesis is not the proximate cause of the possible infanticide, the mother still benefits from a nutritional resource by eating the brain despite losing its formal maternal investment.

We thus conclude that the possible maternal infanticide reported fits the parental manipulation hypothesis and can occur in a group with a poor capacity to raise offspring with multiple breeding females, with birth intervals shorter than 3 months, combined with an estimated low infant survival probability because of physical injuries or apparent weakness.

Acknowledgments We would like to thank Dr Carola Borries and two anonymous reviewers for their helpful comments on a previous version of this manuscript. We are grateful to the Instituto Nacional de Recursos Naturales in Lima for the authorization to carry out field studies at the EBQB (authorizations no. 011-2005-INRENA-IFFSDCB, 071-2005- INRENA-IFFS-DCB, 059-2006-INRENA-IFFS-DCB and 114-2007-INRENA-IFFS-DCB， 106-2007-INRENA-IFFS-DCB) and to export the three $S$. mystax corpses (CITES $\mathrm{N}^{\circ} 11056$ ). We thank Mojca Stojan-Dolar for sharing her unpublished data, Ney and Jeisen Shahuano Tello for assistance in the field, Paloma Nuche Gálvez for help in data collection, and Kerstin Mätz-Rensing for performing the necropsies. This study was made possible by a grant from FRIA (Fonds pour la formation à la recherche dans l'industrie et dans l'agriculture) and FNRS (Fonds National de la Recherche Scientifique), Belgium, to LC. YLF is indebted to Fundación "La Caixa" and Fundación Cajamadrid for personal grants, to the Spanish Ministry for Education and Science (MEC-DGI contract grant no. SEJ2005-00016), and to the Ministry for Science and Innovation (MCINN-SGPI contract grant no. PSI2009-08581PSIC).

\section{References}

Abbott DH, Barrett J, George LM (1993) Comparative aspects of the social suppression of reproduction in female marmosets and tamarins. In: Rylands $\mathrm{AB}$ (ed) Marmosets and tamarins: systematics, behaviour and ecology. Oxford University Press, Oxford, pp 152-163

Achenbach G, Snowdon C (2002) Costs of caregiving: weight loss in captive adult male cotton-top tamarins (Saguinus oedipus) following the birth of infants. Int J Primatol 23:179-189

Arruda MF, Araujo A, Sousa MB, Albuquerque FS, Albuquerque AC, Yamamoto ME (2005) Two breeding females within free-living groups may not always indicate polygyny: alternative subordinate female strategies in common marmosets (Callithrix jacchus). Folia Primatol 76:10-20

Bezerra BM, Souto AS, Schiel N (2007) Infanticide and cannibalism in a free-ranging plurally breeding group of common marmosets (Callithrix jacchus). Am J Primatol 69:945-952

Cäsar C, Franco ES, Soares GCN, Young RJ (2008) Observed case of maternal infanticide in a wild group of black-fronted titi monkeys (Callicebus nigrifrons). Primates 49:143-145

Clutton-Brock TH, Brotherton PN, Smith R, McIlrath GM, Kansky R, Gaynor D, O'Riain MJ, Skinner JD (1998) Infanticide and expulsion of females in a cooperative mammal. Proc R Soc Lond B 265:2291-2295
Curtin R, Dolhinow P (1978) Primate social behavior in a changing world. Am Sci 66:468-475

Dietz JM, Baker AJ (1993) Polygyny and female reproductive success in golden lion tamarins, Leontopithecus rosalia. Anim Behav 46:1067-1078

Digby LJ (1995) Infant care, infanticide and female reproductive strategies in polygynous groups of common marmosets (Callithrix jacchus). Behav Ecol Sociobiol 37:51-61

Digby L (2000) Infanticide by female mammals: implications for the evolution of social systems. In: Van Schaik CP, Janson CH (eds) Infanticide by males and its implications. Cambridge University Press, Cambridge, pp 423-446

Digby L, Saltzman W (2009) Balancing cooperation and competition in callitrichid primates: examining relative risk of infanticide across species. In: Ford SM, Porter LM, Davis L (eds) The smallest anthropoids: the Marmoset/Callimico radiation. Springer, New York, pp 135-153

Digby LJ, Ferrari SF, Saltzman W (2007) Callitrichines: the role of competition in a cooperatively breeding species. In: Campbell C, Fuentes A, MacKinnon K, Panger M, Bearder S (eds) Primates in perspective. Oxford University Press, Oxford, pp 85-105

Ebensperger L (1998) Strategies and counterstrategies to infanticide in mammals. Biol Rev 73:321-346

Emlen ST (1991) Evolution of cooperative breeding in birds and mammals. In: Krebs JR, Davies NB (eds) Behavioural ecology: an evolutionary approach. Blackwell Science, Oxford, pp 301-337

Encarnación F, Heymann EW (1998) Body mass of wild Callimico goeldii. Folia Primatol 69:368-371

Fraser AF, Broom D (1990) Farm animal behaviour and welfare, 3rd edn. Baillière Tindall, London, p 437

French JA (1997) Proximate regulation of singular breeding in callitrichid primates. In: Solomon NG, French JA (eds) Cooperative breeding in mammals. Cambridge University Press, New York, pp 34-75

Garber PA (1997) One for all and breeding for one: cooperation and competition as a tamarin reproductive strategy. Evol Anthropol 6:187-199

Goldizen AW (1987) Facultative polyandry and the role of infantcarrying in wild saddle-back tamarins (Saguinus fuscicollis). Behav Ecol Sociobiol 20:99-109

Goldizen AW, Mendelson J, van Vlaardingen M, Terborgh J (1996) Saddle-back tamarin (Saguinus fuscicollis) reproductive strategies: evidence from a thirteen-year study of a marked population. Am J Primatol 38:57-83

Harvey PH, Martin RD, Clutton-Brock TH (1987) Life histories in comparative perspective. In: Smuts BB, Cheney DL, Seyfarth RM, Wrangham RW, Struhsaker TT (eds) Primate societies. University of Chicago Press, Chicago, pp 181-196

Heymann EW (1995) Sleeping habits of tamarins, Saguinus mystax and Saguinus fuscicollis (Mammalia; Primates; Callitrichidae), in north-eastern Peru. J Zool (Lond) 237:211-226

Heymann EW (2000) The number of adult males in callitrichine groups and its implications for callitrichine social evolution. In: Kappeler P (ed) Primate Males. Cambridge University Press, Cambridge, pp 64-71

Hilário R, Ferrari SF (2010) Double infanticide in a free-ranging group of buffy-headed marmosets, Callithrix flaviceps. J Ethol 28:195-199

Hrdy SB (1979) Infanticide among animals: a review, classification, and examination of the implications for the reproductive strategies of females. Ethol Sociobiol 1:13-40

Hrdy SB (1999) Mother nature: maternal instincts and how they shape the human species. Ballantine Books, New York

Huck M, Löttker P, Bohle UR, Heymann EW (2005) Paternity and kinship patterns in polyandrous moustached tamarins (Saguinus mystax). Am J Phys Anthropol 127:449-464 
Lazaro-Perea C, Castro CSS, Harrison R, Araujo A, Arruda MF, Snowdon CT (2000) Behavioral and demographic changes following the loss of the breeding female in cooperatively breeding marmosets. Behav Ecol Sociobiol 48:137-146

Lledo-Ferrer Y, Hidalgo A, Heymann EW, Peláez F (2009) Field observation of predation by a slate-colored hawk, Leucopternis schistacea, on a juvenile saddle-back tamarin, Saguinus fuscicollis. Neotrop Primates 16:82-85

Löttker P, Huck M, Heymann EW (2004) Demographic parameters and events in wild moustached tamarins (Saguinus mystax). Am J Primatol 64:425-449

Lunn SF, McNeilly AS (1982) Failure of lactation to have a consistent effect on inter-birth interval in the common marmoset, Callithrix jacchus jacchus. Folia Primatol 37:99-105

Melo L, Mendes Pontes AR, Monteiro da Cruz MAO (2003) Infanticide and cannibalism in wild common marmosets. Folia Primatol 74:48-50

Nievergelt CM, Digby LJ, Ramakrishnan U, Woodruff DS (2000) Genetic analysis of group composition and breeding system in a wild common marmoset (Callithrix jacchus) population. Int $\mathbf{J}$ Primatol 21:1-20

Porter LM (2001) Social organization, reproduction and rearing strategies of Callimico goeldii: new clues from the wild. Folia Primatol 72:69-79

Roda S, Mendes Pontes A (1998) Polygyny and infanticide in common marmosets in a fragment of the Atlantic Forest of Brazil. Folia Primatol 69:372-376

Saltzman W, Pick RR, Salper OJ, Liedl KJ, Abbott DH (2004) Onset of plural cooperative breeding in common marmoset families following replacement of the breeding male. Anim Behav 68:59-73

Sambraus HH (1985) Mouth-based anomalous syndromes. In: Fraser AF (ed) Ethology of farm animals, World Animal Science, vol A5. Elsevier, Amsterdam, pp 391-422

Sanchez S, Pelaez F, Gil-Burmann C, Kaumanns W (1999) Costs of infant-carrying in the cotton-top tamarin (Saguinus oedipus). Am J Primatol 48:99-111

Sanchez S, Pelaez F, Morcillo A, Gil-Burmann C (2005) Effect of the enclosure on carriers' body weight loss in the cotton-top tamarin (Saguinus oedipus). Am J Primatol 66:279-284
Schneider ML, Roughton EC, Koehler AJ, Lubach GR (1999) Growth and development following prenatal stress exposure in primates: an examination of ontogenetic vulnerability. Child Dev 70:263-274

Smith AC, Tirado-Herrera E, Buchanan-Smith HM, Heymann EW (2001) Multiple breeding females and allo-nursing in a wild group of moustached tamarins (Saguinus mystax). Neotrop Primates 9:67-69

Solomon NG, French JA (1997) The study of mammalian cooperative breeding. In: Solomon NG, French JA (eds) Cooperative breeding in mammals. Cambridge University Press, Cambridge, pp $1-10$

Tait DEN (1980) Abandonment as a tactic in grizzly bears. Am Nat 115:800-808

Tardif SD (1994) Relative energetic costs of infant care in smallbodied neotropical primates and its relation to infant-care patterns. Am J Primatol 34:133-143

Tardif SD, Harrison ML, Simek MA (1993) Communal infant care in marmosets and tamarins: relation to energetics, ecology, and social organization. In: Rylands $\mathrm{AB}$ (ed) Marmosets and tamarins: systematics, behaviour and ecology. Oxford University Press, Oxford, pp 220-234

Tirado-Herrera E, Knogge C, Heymann EW (2000) Infanticide in a group of wild saddle-back tamarins, Saguinus fuscicollis. Am J Primatol 50:153-157

Vleeschouwer K, Van Elsacker L, Leus K (2001) Multiple breeding females in captive groups of golden-headed lion tamarins (Leontopithecus chrysomelas): causes and consequences. Folia Primatol 72:1-10

Voland E, Stephan P (2000) "The hate that love generated"sexually selected neglect of one's own offspring in humans. In: Van Schaik CP, Janson CH (eds) Infanticide by males and its implications. Cambridge University Press, Cambridge, pp 447-465

Ziegler TE, Bridson WE, Snowdon CT, Eman S (1987) Urinary gonadotropin and estrogen excretion during the postpartum estrus, conception, and pregnancy in the cotton-top tamarin (Saguinus oedipus oedipus). Am J Primatol 12:127-140 